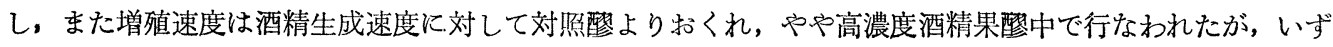
れも到達した最高数には大差がなかつた。

2. 甲州種とミルズは最初の自然醉母数やブドウ酒醳母の割合等に著しい差があつた。また全酵母数の最 高はミルズでは甲州種の $1 / 2$ 程度に止まつたが，これは高温醱酵が主原因の一つに考えられた。

3. 野生酵母群の生菌数割合を得るに稀釈果汁寒天を用いPlate count する方法を試み, 従来の斜面採 取法と比較したが，極めて簡易であり且つ信頼度の高い結果が得られた。

4. 野性醭母の割合は $\mathrm{SO}_{2} 50 \mathrm{ppm}$ 添加の果醪 (KS) では, 最初明らか炕著るしく打撃を受けて減少す るが, その後急速に増加し，その生菌実数の最高は対照と同程度まで増加した。このことは亜硫酸で野生醉母 を抑制する観点からは注目しなければならない。いずれも糖分（屈折度）が低下し始めた頃その割合は最高 に達し, 実数の增加はその後も続く場合もあるが酒精濃度 1 3\% の間に著るしく活性を失わない $12 \%$ に 到つて活性野性醉母は全く消失した。

5. 全醉母数曲線の対数期の初め屈曲点を認めたが，この時期は多くの野生醉母が活性を失う時期と一致 した。また野生醭母の割合が亜硫酸添加試料儿おいて 20 時間後頃比較的高い值を示した原因の一つとして ブドウ酒酵母群の活性が低下すること.が推定された。

\title{
交献
}

1) CRuess, W. V.: Principles and Practice of wine making. p. 172, Avi Publ. Co. New York(1949)

2) BALdwin, G. N.: Proc. Am. Soc. Enologists, 2 nd Annual Open Meeting, Davis, Calf., Aug. 9-10, p. 43 53 (1951); Reviewed by M. A. JosLYN : Wines \& Vines, 35(12), 31 (1954)

3) SAENKo, N.F.: Vinodelie i vinogradarstvo s.s.s. R., 6 (2), 12 (1946)

4) Schandel, H.: Die Mikrobiologie des Weines. E. Ulmer, Stuttgart (1950)

5) LAFOURCADE, S.: Ind. agr. et aliment., 71, 15 (1954)

6) BEeCE, I. F. W. et al.: Ann Rep. Ag. and Hort. Res. Sta., Long Aston, Bristol, 1951(1952);

7) 坂口䜕一郎：園雑, 29 (1934)

8) EChells, J.L. et al.: App. Microbiol., 2, 296 (1954)

9) 大西博: 瀑化, 28, 134 (1954)

(山梨大学工学部醱酵研究所)

\section{クロマトグラフ分析法の成果 (I)}

清酒に対する分析成果

秋山裕一

(昭和 308 月 11 日受理)

近年クロマトグラフィー特にその中でもペーパー・クロマトグラフィー (ペーパー法) は化学者にとつて 恰も試験管を振るのと同杼になくてはならない実験道具となつた。そのもたらす成果は試料, 労力僅少に比 して実に偉大なるものであつて, これを発明し（1944 年昭 19 年）, 更にあらゆる方面に発展させたのはコ ンスデン (Consden), ゴードン (Gordon), マーチン (Martin), シンヂ (Synge) 氏等である(ノーベル 賞 1952)。本法が発明されて以来，僅か 10 年余であるが，その応用領域は有機，無機を問わず，又核分裂 の生成物から高分子の蛋白質に到るまで化学の全分野に亘つて利用されない面はなく, 更に深い研究改良が なされて, その進展は非常に急速である。最近濾紙電気泳動法や更に本法の応用である連続濾紙電気泳動法 又澱粉によるZ Zone electrophoresis によつて蛋白質や醭意の研究が盛になりつつある。これ等の方法はこ れ迄のクロマトグラフ分析法（滤紙法・イオン交換樹脂法, 或はシリカゲル或はアルミナ等吸着剤によるカ

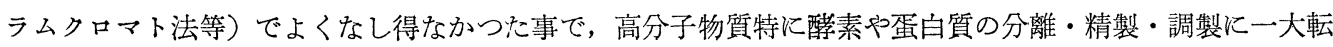
換を来するのと考光るので，ここに醳素及び蛋白質のクロマトグラフィーとクロマト法による清酒分析の成 果とを一括し紹介したいと考光る。

クロマトグラフィーの原理及び成果については既に幾多の成書が出版されているし, 又本誌 46 巻 2 号に 穂積・佐藤氏が解説と応用例を示している。原理及び実駼法と清酒に対する研究結果の大要は山田正一先生 著「醇造分析法」369 431頁に実験方法々共汇記載されているので参照されたい。先ず本法により得られた 
清酒の研究及びこれに関係あると考えられる研究結果について記す事にする。

アミノ酸： 既に 6 年前科学研究所大高洋一氏(1) とより 15 種類が検出され, 量的にもその概略が表示さ れた。現在迄に知られた清酒中のアミノ酸は東大・田村学造氏等(1a) 汇よる乳酸菌を用いた定量法(バイオア

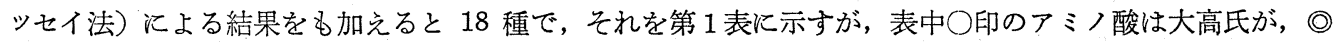

第 1 表 清酒中のアミノ酸（10l 亿換算）

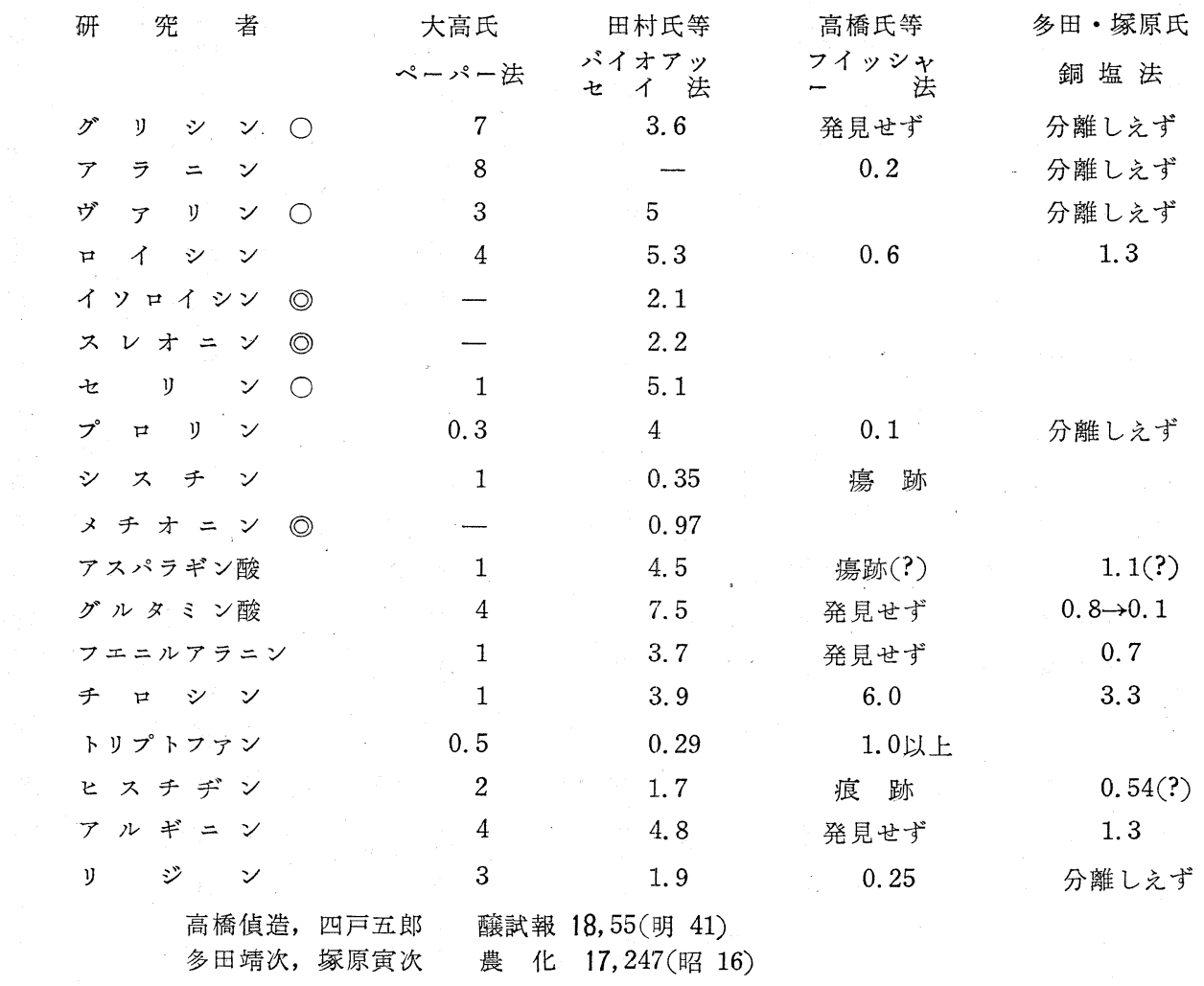

第 2 表 清酒中の核酸物質

$$
\begin{aligned}
& \text { 大高 }
\end{aligned}
$$

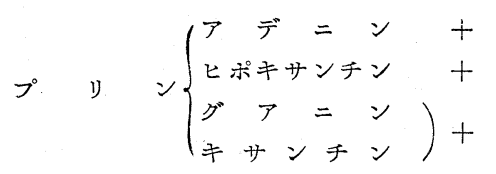

$$
\begin{aligned}
& \text { ピりミデン }\left\{\begin{array}{lllll}
ウ & ラ & シ & ル \\
シ & ト & シ & ン \\
f & & \Xi & \searrow
\end{array}+\right.
\end{aligned}
$$

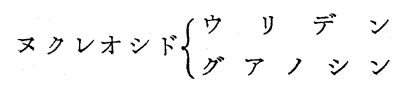

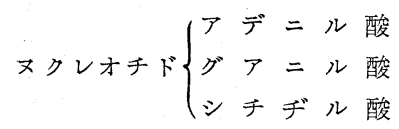

$$
\begin{aligned}
& \text { 猿野 } \\
& \mathrm{m} / \mathrm{l} \\
& 0.05 \\
& \text { 2. } 36 \\
& 0.13 \\
& + \\
& + \\
& +
\end{aligned}
$$

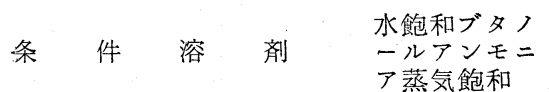

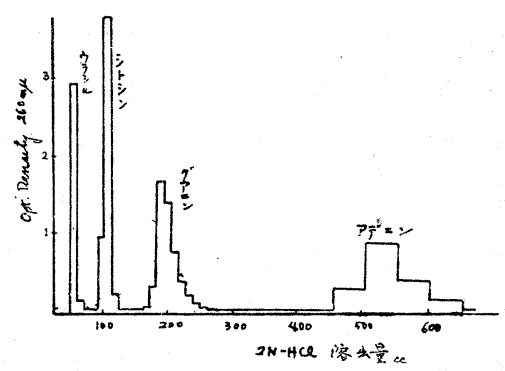

第 1 図 陽イオン交換樹脂によるプリン・ ピリミデン塩基の分離

樹 脂 Dowex-50 H型 300 メッシュ $8.1 \mathrm{~cm} \times 0.74 \mathrm{~cm}^{2}$

溶出剤 $2 \mathrm{NHCl} 0.6 \mathrm{ml} /$ 分

は田村氏が新に検出したものである。清酒中の アミンについては新しい報告はない。以来各研究 者によつて行われて和り, 現今溶剤としてブタノ

展開 降 法上昇法チプル
発回マル
色 水塩と 紫色線

ール・醋酸系とフェノール系とが主として用いら れていて，もうとりたてて書く事もない程当り前 の研究手段となつてしまつている。科研守随稀 雪, 坂本政義, 田島修氏 $(1 \mathrm{~b})$ 等は本法を縦横に駆 使して, 脱脂大豆蛋白 (K.C.P.) その他の蛋白 
質の利用による合成清酒香味の增強の研究を発表している。

核酸成分： 大高氏(2)はブタノールで展開プリン及びピリミデン塩基のうらアデニン，ヒポキサンチン， グアニン或はキサンチン及びシトシンを水銀塩発色法により検出した。日本酒類 KK 猿野琳次郎 ${ }^{(22)}$ 氏は合 成清酒の研究に於て清酒々合成清酒とは紫外部吸収が非常に異つている点より核酸物質に注目研究し, 大高 氏の認めた塩基と更にヌクレオシド（ウリデン，グアノシン） ヌクレオチド（アデニル酸，グアニル酸、シ チデル酸）を検出した。ヤマサ醬油 KK 国中明(3)氏も核酸分解酵素の研究にペーパー法を有効使用して いる。之等核酸類は紫外線吸収を示すので，猿野氏は $5 \mathrm{~W} 60$ サイクル，0.3A の殺菌用紫外線ランプを暗 箱に設け，空に科研フィルター $(253 \mathrm{~m} \mu)$ をとりつけ，之を濾紙照射して罃光スポットを検出する。或は 写真印画紙を密着させて紫外線を照射して現像すれば黒地の印画紙に白のスポットを生ずる。第 2 表に方法 及び結果を一括する。

W.E.Cohn 氏一門(4) はイオン交換樹脂によつて核酸成分を分離定量しているが，カチオン交換樹脂による 塩基の分離結果を第 1 図に示す。R.Parsons 氏(5) はビール麦芽汁中より Amberlite IR120，N-アンモニア 溶出で adenosine 及び guanosine を分離した。樹脂による清酒中の核酸の研究は未だ発表されていない。

糖類： 糖はペーパー法によつて一次元・多重展開法 (Multiple chromatography) 汇よつて分別定量が 行われ, ペーパー法による定量分析の代表的なものである。東北大学麻生清教授, 柴崎助教授等 $(10)$ 飞よつて 非酸醅性糖に関する広汎な研究がなされている。清酒中に葡萄糖（約 $80 \%$ 全糖に対し）の他に二糖類とし てイソマルトース Isomaltose ( $\alpha \cdot 1-6$ 結合, .5 12\%), サケバイオース Sakébiose $(\alpha \cdot 1-3$ 結合, 1 2\%) コージバイオース Kojibiose ( $\alpha \cdot 1-2$ 結合, 1 3\%), 三糖類としてパノース Panose ( $\alpha \cdot 1-4,1-6$ 結合, 1４\%), デキストラントライオース Dextrantriose（構造不明, 2〜3\%) 及び四糖類, デキストリン（4〜 $6 \%$ ) 等新しい糖類を検出, 定量し, 更に糊汁及び清酒よりセライトによるカラム法によつて Isomaltose 及 び Kojibiose の醋酸誘導体を結晶状に単離し, その構造, 結合様式を研究し, 一研究法として後述する濾紙

\section{第3表 清 酒 9 糖 成 分}

\begin{tabular}{|c|c|c|c|c|c|c|c|c|c|c|c|c|}
\hline 分 & 析 & 者 & & 生 & 氏 等 & & $\begin{array}{l}\text { 富金原 } \\
\text { 等 }\end{array}$ & 仙台全 & 定室 & 津 山 & 氏等 & \\
\hline & & : & 清酒 & $\begin{array}{l}\text { 三倍 } \\
\text { 葡萄糖 }\end{array}$ & 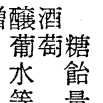 & 水飴 & & 葡䓨糖 & 水飴 & $\begin{array}{l}\text { 三倍増 } \\
\text { 液状グル } \\
=\end{array}$ & 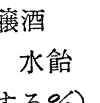 & $\begin{array}{l}\text { 全糖に } \\
\text { 詨する } \\
\text { 割合 }\end{array}$ \\
\hline 全 & & 糖 & 4.53 & 4.12 & 4.53 & 4.58 & 3.93 & 3.75 & 3.65 & & & \\
\hline 縟 & 元 & 糖 & 3.77 & 3.52 & 3. 81 & 4.07 & 2.74 & & & & & \\
\hline$テ$ & ストリ & ン & 0.68 & 0.54 & 0.65 & 0.46 & 1.63 & & & & & \\
\hline 葡 & 萄 & 糖 & 3.69 & 2.97 & 3.37 & 3.90 & 2.12 & 3.08 & 2.75 & 82 & 80 & $72 \sim 85$ \\
\hline & ébiore & & 0.08 & 0.08 & 0.11 & 0.06 & & & & & & \\
\hline & biore & & 0.08 & 0.08 & 0.12 & 0.05 & & 0.22 & 0.16 & 1 & 2 & \\
\hline & naltose & & 0.33 & 0.47 & 0.48 & 0.25 & 0.71 & 0.62 & 0.52 & 13 & 13 & $5 \sim 12$ \\
\hline & ose & & 0.08 & 0.15 & 0.12 & 0.04 & 0.26 & 0.23 & 0.30 & 1.5 & 1.5 & $1 \sim 4$ \\
\hline & trantri & & 0.08 & 0.13 & 0.15 & 0.08 & & & & & & \\
\hline & $\operatorname{trin}$ & & 0.20 & 0.23 & 0.18 & 0.18 & & 0. & 0.38 & 3.5 & 5 & 5 \\
\hline
\end{tabular}

電気泳動法汇より Sakebiose 及び Kojibiose が $\alpha \cdot 1-3$ 及び 1-2 結合である事を確認しつつある。

三倍増䁔酒中の糖成分は興味深いものであつて, 分 解度の高い（約 $80 \%$ 分解度）グルコースでも，低い 水飴（約 $40 \%$ ) いずれを添加して子数日後には米だけ から造つた清酒の糖組成とほぼ同一になつてしまう。 これについては科研富金原孝氏等(6) 仙台鑑定官室 ${ }^{(11)}$ 更に参松工業 $\mathrm{KK}$ 津山英夫, 高橋是氏(7) るほぼ同様 の結果を報告している。之を第 3 表浪一括する。この 糖成分の变換は麭炕由来すると考兄られる醳素トラン スグルコシダーゼ（䤏母にもこの作用がおる(12) と云 5)や $\alpha-$ アミラーゼの作用によつて, 麦芽糖がその

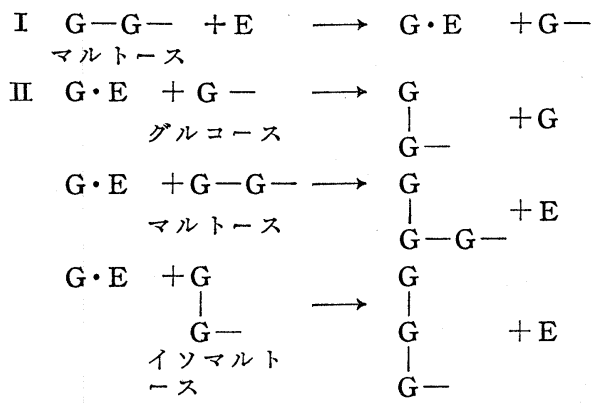

第 2 図トランス作用模型

G- glucose 単位 (遊離アルデヒドキ)

E トランスグルコシダーゼ 作用の中心になつて，葡萄糖の比較的結合数の少い寊糖類（その限界は不明）に互に変換しあう事を示すも 
参照すべきと考える。

有機酸：大高氏(14)はイオン交換樹脂で酸を集積し, 之を溶出させてぺー パー法により苳酸, クエン酸, リンゴ酸, 乳酸, コハク酸, フマール酸, 燐 酸, 䊍酸を検出した。スポットの位置は第 5 図の如くであるが, 有機酸の $R_{f}$ は比較的変りやすいので, 純品を対称として上げると同時に色々の発色法, 種々の溶剤の使用により確認する事を要する(14)。麭酸があれば滤紙中を赤

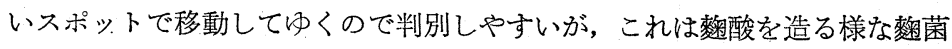
を使 $と$ と多量に検出される (当所村上技官未発表)。

東洋醸造 KK 川野義男, 川端修一氏 ${ }^{(15)}$ はシリカゲルクロマト法により酸を 分別分析し，優良酒には乳酸の方が琥珀酸より多いと報告し，猿野氏(16) も エーテル抽出の有機不揮発酸につきシリカゲルにより定量した。更に最近大 高氏は「清酒成分の系統的研究」(17) に於てイオン交換樹脂により分別した酸

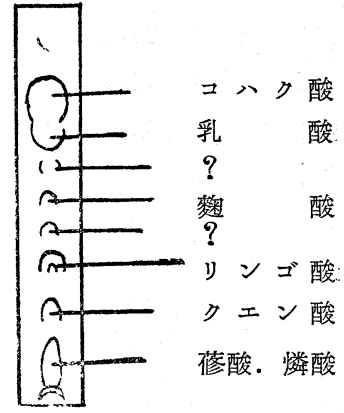

第 5 図 有機酸の ペーパークロマ ト(14) 区分について,シリカゲル法により定量した。之等の結果は第 4 表に一括するが, リンゴ酸やマロン酸量が 第 4 表 清酒中の有機不揮発酸 $(\mathrm{mg} / 100 \mathrm{cc})$

\begin{tabular}{|c|c|c|c|}
\hline 分 & 析 & 者 & \\
\hline 琥 & 珀 & 酒 & \\
\hline 乳 & & 酸 & \\
\hline ע & 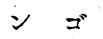 & 酸 & \\
\hline ク & I & 酸 & \\
\hline 不 & 明 & 酸 & \\
\hline$\nabla$ & म ע & 酸 & \\
\hline 7 & $\nabla-ル$ & 酸 & \\
\hline 苳 & & 酸 & \\
\hline ピ & ルビン & 酸 & \\
\hline 憐 & & 酸 & \\
\hline 参 & 考 & 大 & 崎 \\
\hline
\end{tabular}
川 野 - 川端氏 市販合成 50-70 10-30 $-$

$$
\begin{gathered}
\text { 市販 } 2 \text { 級 } \\
23-60 \\
30-60 \\
+ \\
2.0-6.6 \\
+ \\
+ \\
+ \\
+ \\
+
\end{gathered}
$$$$
\text { 2. } 0-6.6
$$

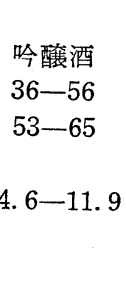

猿野氏 香味液

92.0

104. 0

3.4

8. 9

61.0

29.0

16.6

14. 2

11.6

1. 7

3. 3

$+\quad 1.0$

琥珀酸 1 : 乳酸 2 3.5, 䁔学 12,1 (昭 9 )

58.0

" $11 \mathrm{~g} " 7 \mathrm{~g}$, 醋酸 $5 \mathrm{~g}$

山广配清酒 $30 l$ より, その他酸認めず 醇試報 127,13 (昭 13)

西崎氏

琥珀酸 $0.063 \%$ 乳酸 $0.110 \%$ 楽誌 287 号 (明 38 ), 330 号 (明 41)

森 三也氏

安藤福三郎氏

黒 野 氏等

"

$0.1301 \%$

" 0.0872

" 0.0717

0.0229

酻試報 25,68 (明 42 )

" 0.0870

"

0.1100 (吟䤑)

0.1053

0.1238 (並酒)

醸協, 30, 876 (昭.10)

比較的多量に存在するのは醱醭機作と関連して興味ある問題であり, 又従来より問題のコハク酸と乳酸との 量比は区々であり, 東北大学植村定治郎教授等 ${ }^{(40)}$ による清酒醭母の乳酸及びコハク酸の生成メカニズム(清 酒䤉母の生理) が研究されており，将来に残る問題である。

清酒中の有機酸はある部分は塩の形で含有されていると考兄られるが，大高氏(14) はイオン交換樹脂によ つて約 $27 \%$ が結合酸と報じた。川野氏等は清酒そのままと硫酸々性エーテル抽出とイオン交換樹脂法とに よつて遊離酸は 55〜70\%，塩形は 22〜 40\% で，吟䤑は二級より塩形が少い(高精白の為ならん)。各酸につ いては琥珀酸は $95 \%$ 位, 乳酸は $60 \sim 70 \%$ が遊離酸, クエン酸は約 $90 \%$ が塩形, 粼酸は殆んど全部塩形 として存在する。

ケト酸 : 大高氏(14), 川端氏(15)等, 䤑造試験所 榎徹, 武藤浩氏 ${ }^{(13)}$, 猿野氏 ${ }^{(19)}$, 及び大倉酒造 $\mathrm{KK}$ 安 藤智雄, 栗山一秀, 赤見坂聰氏(20) 等報告が多く, いずれも $2 \cdot 4-$ ヂニトロフェニルヒドラデンによりケト酸

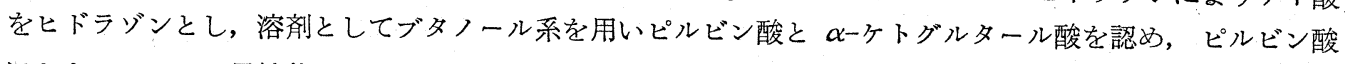
にケトエノールの異性体のある事を認めた(15)。これ等ケト酸は醱酵の中間物とし重要な物質であるばかり

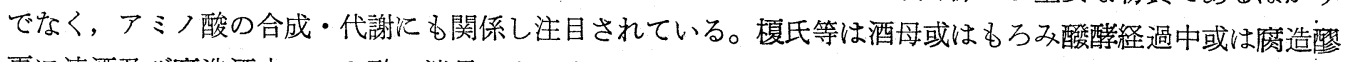
更に清酒及び腐造酒中のケト酸の消長を山田先生発見のロテラ呈色法 ${ }^{(39)}$ により比較し, 糖の多い酒母, る万 みの初期, 或は腐造酒には相当量検出されるが, 正常酸酵をした清酒中には認められない(18) と云う。之に対 し川端(15), 猿野(19), 安藤(20)氏等は量的には相違はあるがいずれにも検出されると報告している。定量する と, 安藤氏は腐造酒中には正常酒より多い傾向にある（反対の場合もある）けれども量的にも質的にも両者 
ので，例えのば第 2 良の如くである。このトランスグルコシダーゼ作用は葡萄糖の 1-4 或は 1-6 結合の みではなく 1-2或は 1-3 結合も生成するものと考光らる。之等 1-2 或は 1-3 結合の酵素的生成につ いては証明されてはいないけれども, 教育大学三輪知雄教授は䤉素的糖転位の場合にこう云う結合が偶然に

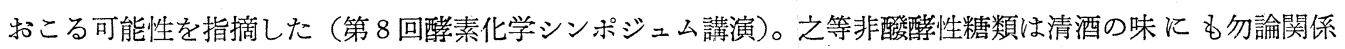
するだろらけれども,アルコール酸䤉の残糖として見落せないるのである。これが多い場合はアルコール収 率が低下寸るわけであるが，アルコール工業での必要な激粉分解酵素系の組成についてアミラーゼ研究会 ( 東京中心のアミラーゼ関係研究者の集り)で多く研究発表討論が重ねられ, アルコール酸醭の収量を予測出 来るような酵素力の測定法を提出した (9a)。この非酸酵性糖頪の生成は transglucosidase 作用が強く更にこ の酵素の基質であるマルトースを生成する $\alpha$-amylase が強い場合に多く生成する(糸状菌の $\beta$-amylase は gluc amylase で栽萄糖のみを生成する $\left.{ }^{(9)}\right)$ 。最近三共製薬 KK 岡崎浩氏 ${ }^{(9)}$ は各種糸状菌アミラーゼ系 の研究に於て各種糸状菌の $\alpha$ 及び $\beta$ (saccharogenic) アミラーゼ及びトランスグルコシダーゼ（trans と 略）力を測定し, 糖化の伸びと生成糖類との関係, またそこに醉母が存在する場合即ち並行複酸醭の場合の :糖化, 酸醳の関係を明確にした（生成糖類はすべてぺーパ法で確認している）。その結果黄驇菌は $\alpha$-am が非常に強く $\beta$-am 及び trans は弱いので酵母の存否に関せず糖化の伸びは同じであまりよくない（88\% 以下)。之に対して黒麴菌 Asp. Usamii 及びRh. tonkinensis は $\beta$-am 及び trans は強力であるが $\alpha$-am が弱い為に trans 作用がないから醉母の存否に関せず伸びは共に良く $90 \%$ 以上飞達する。所が Asp. awamori は $\alpha$-am 子相当強く, $\beta$-am も trans 子強いから酵母のない時は生成糖が trans 作用によつて再合 成され糖化の伸びが悪い( $80 \%$ 以下)。しかし醭母があると伸びの初速はおそいが酸酵後期になるとUsamii 菌の場合々同一になる。これは酸酵の初期, 酵母の增殖期には trans 作用が行われるが, 後期糖が消費さ れると trans 作用の逆反応が起きて非醱酵性糖が再び醱酵性梼に変り消費されるからである。この結果は

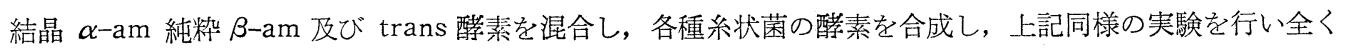

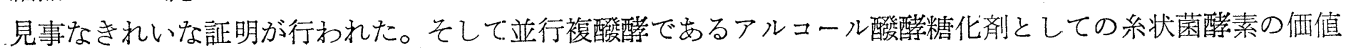
判定に対して G.D. 説を提唱した。即ち G.D.と云うのは澱粉から生成する葡萄糖の初速度を示するので “Glucose-Direct” activity 即ちG.D. と名付け, 糖化醳素量に相当する。之を測定すればアルコールの収 率が予測出来ると云うわけである。

清酒もろみの酸醅経過中の糖分の变化については山邑酒造 KK 险山公雄, 杉田修氏等 ${ }^{(8)}$ により研究され,

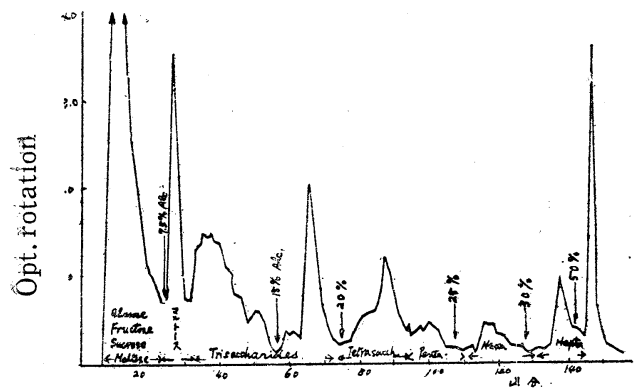

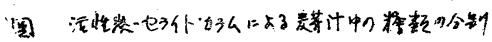

第 3 図 活性炭・セライトカラムによる 麦芽汁中の糖類の分別 従来問題となつていた清酒中の麦芽糖の存在は水飴添 加の場合でも(6)(10)ペーパー法によつて完全に否定さ れた。

ビール或は麦芽汁中の糖類についての研究も主とし てこのペーパー法で行われているが, 活性炭・セライ トカラム, アルコール溶出法による第 3 図の如き定量 を行い，醉母の変異株による「くいきり」とその酵母の トランスグルコシダーゼ作用を報告している(21)。マッ クファーレン (W.D.Mc Farlane)(13)氏等は濾紙クロ マトパイル法により麦芽汁中の各種糖類を定量し, 果 糖 $0.15 \%$, 葡萄糖 $1.03 \%$ 蔗糖 $0.42 \%$, 麦芽糖 6.04 $\%$ malttriose $1.77 \%$, malttetraose $0.72 \%$, 高級デ キストリン $2.68 \%$ ，しかし醱酵したビールでは前四糖は消失している。

濾紙クロマトパイル法とは第 4 図の如きステレン大製体の中に濾紙（普通7 又

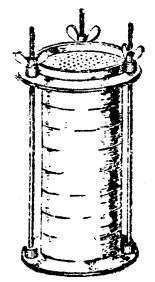
は9cm）を500１000 枚を置き，試料は同一濾紙約 50 枚位にしみこませ，之 を風乾して後この上にかさね, 更にその上に濾紙を30４0枚位かさねて，枠で しつかり止める。之を密閉器（上方に穴のあるデシケーターーが便利）中に入れ上 から溶媒を滴下させて展開する。この滴下速度は適宜決めなければならない。展 開終了後各物質の存在部位は紫外線を照射して營光を見るとか, 呈色試薬をペン でつけて発色させて確かめて後との部を抜きとつて抽出する。 $9 \mathrm{~cm}$ 円形濾紙を 用いると約 $100 \mathrm{mg}$ 位の物質を処理し得る。物質の抽出分離は容易であるが一般

第4図クロマトパイル にあまり使われていない。

ペーパー法による糖類発色条件, 色調及びその变化に関しては麻生教授等の報告（酳工 33,119 , 昭 30) を 
表してい判別の指標とはなし得ないと云つている。川端氏等は並酒よりむしろ優良酒に多く $(10 \mathrm{~m} \%$ に対し 17 30\%) 三增酒にも多い (13〜18 m\%)（安藤氏む同じ結果を報告)。酒母では休及時最高（約 $0.1 \%$ ) を 示し急激に減少し, 整でも0.07\%(13日目頃) 最高で後減少する。この減少速度の拈そいものが優良酒に多 いと云う。多くの問題がありそうであるが，本問題については筆者は門外漢であるから各研究者の発表を紹 介するに止める。後榎氏等はケト酸が腐造の指標になるとの自説を取消した。(18)

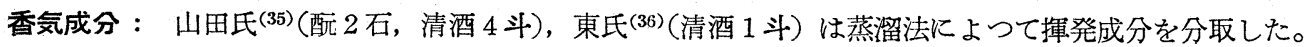
山田氏は揮発成分として揮発酸に醋酸(一部蟻酸?), 揮発性アミンとしてカタベリン, フーゼル油としてイ ソアミルアルコール (主成分) とイソブチルアルコール (2/3 量) 活性アミルアルコール (1/4 量) プロピル アルコール(?), 更に高沸点部にエステルとしてパルミチン酸, ステアリン酸のエチルエステル（エステル 分は酛液中に多いが水不溶性の為粕中に移行し清酒中には少い), 及びアルデヒド類を検出した。東氏はプロ ピルアルコール, 醋酸プロピル, 醋酸エチル, 乳酸エチル等を認めた。守随氏等(37)は逆に各種の合成エステ ルのうち n-バレリアン酸及び n-カプロン酸エチルエステルが呤䤑香に極めて近い事を報じた。東大農芸化 学山本銀三, 嘉納成三, 菅間誠之助氏(21) はわずか $500 \mathrm{cc}$ の清酒によつて種々の香気成分を検出した。 $\mathrm{pH}$ 7.8 及び酸性に於けるエーテル抽出液によつて遊離酸としてイソヴァレリアン酸, カプロン酸, カプリル酸, 蟻酸, 醋酸を, エステルとして蟻酸, 乳酸, 醋酸, n-ヴァレリアン酸, イソヴァレリアン酸を検出し, 存在 を予想された琥珀酸エステルは検出されなかつた。nーヴァレリアン酸などはどこから生成されるものだろう か。氏等は山田氏の分離確認したパルミチン酸, ステアリン酸等高級脂肪酸のエステルについては全くふれ ていない。これは之等成分の $R_{f}$ が大きく分別し得ない為で有機溶媒を固定層とするクロマトによれば高級 脂肪酸の分別も可能であると云う。

アルコール類のペーパー法は酺造分析法を参照されたいが，アミノ酸や有機酸と異つてそのままではク口 マト法では分別し得ないで、一度誘導体をつくらねばならないからあまり報告はない。最近科学研究所服部 行彥(38) 氏は清酒の香気成分を分離確認しょうと清酒粕 $465 \mathrm{~kg}$ の減圧水蒸気蒸溜により香気成分を捕集し （僅か 28g）この5ち7区分（約 20g）を 3,5-ジニトロ安息香酸エステルとして，シリカゲルカラムクロマ 卜法 (紫外線検出して溶出) によつてエチルの他に n一プロピル（従来存否が問題になつていた）、イソブチ ル及びアミルアルコールが確認された。この区分はフーゼル油様香以外に僅かに果実様エステル芳香を感ず るが酸部は検出し得なかつたと云う。更に高沸点区分については目下研究中である。（第 5 表参照）

第 5 表 清酒の揮発成分

$$
\begin{aligned}
& \text { アルコール類 プロピルアルコール(東)(服部)(山田?), イソブチルアルコール(山田)(服部) } \\
& \text { イソアミルアルコール(山田)(服部), 活性アミルアルコール(山田) } \\
& \text { メチルアルコール(高橋), エチルアルコール,ブチレングリコール(山田)(富安) } \\
& \text { フェニルエチルアルコール(東) }
\end{aligned}
$$

脂 肪 酸 類、蟻酸(山田)(山本), 酷酸(山田)(山本), イソヴナレリアン酸(山本)

カプロン酸(山本), カプリル酸(山本)

エステル類、醋酸エチル(東)(山本), 醋酸プロピル(東), 蟻酸エチル(山本)

乳酸エチル(東)(山本)， nーヴァレリアン酸エチル(山本)

イソヴアレリアン酸エチル(山本)

パルミチン酸エチル(山田), ステアリン酸エチル(山田)

琥珀酸エステル 検出されず

アルデヒド類アセトアルデヒド(山田), バレルアルデハイド(山田), フルフラール樣物質(山田)

アセタール(東)?

ア ミン・ダベン(山田)

方 レン ダイアセチル(山田)(庄司)(富安),アセチルメチルカルビノール(山田)(庄司)(富安)

一クロマト法で検出されたもの

アルデヒド及びヶトンについては一般に研究も少いが，清酒についての発表は未だ見ていない。

無機イオンについては東京局鑑定官室佐藤信技官 ${ }^{(22)}$ がペーパー法による醸造用水中の $\mathrm{Ca}$ 及び $\mathrm{Mg}$ の簡 易迅速定量法を提唱した。

この様に清酒の成分が勿論完全と迄はいかないけれども，醸造試験所開設以来 50 年になるが，その間に 殆んど不可能であり, 或は大量の処理により可能となつた各種成分もこの数年の間にクロマト法の威力によ つて一挙に明るみに出されつ〉ある。しかしペーパー法は微量な試料で多種類の成分を分析検出し得るし， 
又種々の工夫改良がなされて定量的に或は分離調製出来るようになつたものもある〔例えばスポットの切断 抽出 (一次元法には適用), スポットの面積, 光電比色計の応用了けれぞも, やはりこの点がペーパー法の弱 点でオールマイテイではない事に注意しなければならない。この弱点を補つて定量分析或は物質の分離調製 に広く用いられるに到つたのがシリカゲル, 搌粉或は活性アルミナ等によるカラム法, 濾紙クロマトパイル 法, イオン交換樹脂法更に液相間で行われるカウンターカレント法 (Counter current distribution) 等で あつて，我々は之等を応用して清酒の構成々分をありのままの形で分離結晶として取り出す事も一つの大き な責務である。このうち最も有用な方法はイオン交換樹脂法であろう。

大高氏 ${ }^{(17)}$ は之等上記の各種のクロマト法を並用して清酒成分の系統的分析を行いつつある事は前述した。 イオン交換樹脂法によつても「酸」は満足すべき分析結果が得られて(23)いるが，清酒については未だ発表さ れていない。アミノ酸に関しては米国ロックフェラー研究所シュタイン (W.H.Stein) 及びモーア (S. Mo-

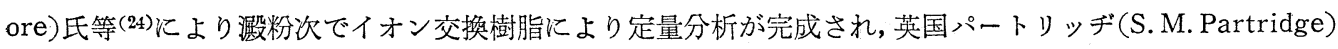

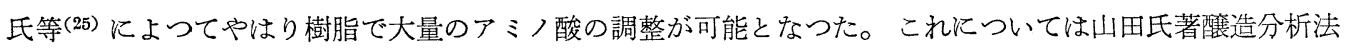
420 頁を参照されたいが前者は全アミノ酸につきほぼ完全な収率によつて分析出来るが, 調製には不向であ る(然し研究改良されている)。之に反して後者は $280 \mathrm{~g}$ の卵アルブミン加水分解物より約 $60 \%$ の収率で直接 結晶アミノ酸を得ている。大阪大学赤堀教授等(26)はタカアミラーゼ A の結晶のアミノ酸組成を Stein 氏等 の方法によつて全分析し, 第 6 表の如き結果を報じ, 文同教授の学士院賞となつた蛋白質構造研究に対する 末端基アミノ酸の定量及びアミノ酸配列順位の決定は蛋白の部分的加水分解物の誘導体について上記のクロ マト法によつたものである。ちなみにアミラーゼA (タカデアスターゼより分離した $\alpha$-amylase) は分子量 53000, DNP 法或はピペラヂン法による末端 $\mathrm{N}$ アミノ酸及び C アミノ酸は $\mathrm{N}$ 末端としてアラニン, C末端 セリン, グリシン及びアラニンがあつて内部の枝分れ或は結合順位はなほ不明であるが第 6 図の如き構造を していると云う。文同氏等は之等の方法によつて, 醭素の活性化機構を研究し, キモトリプシノーゲンが活 性キモトリプシンになる為には酵素プペシン或は自触媒によつていくつかの中間段階をへるが，この間に可 成り大きなペプチド（構造は既にクロマト法により判明）が 3 個はずれて来ると云う (27) 興味ある研究を発

第 6 表 タカアミラーゼ A, 清酒及びビールの溷濁物質のアミノ酸

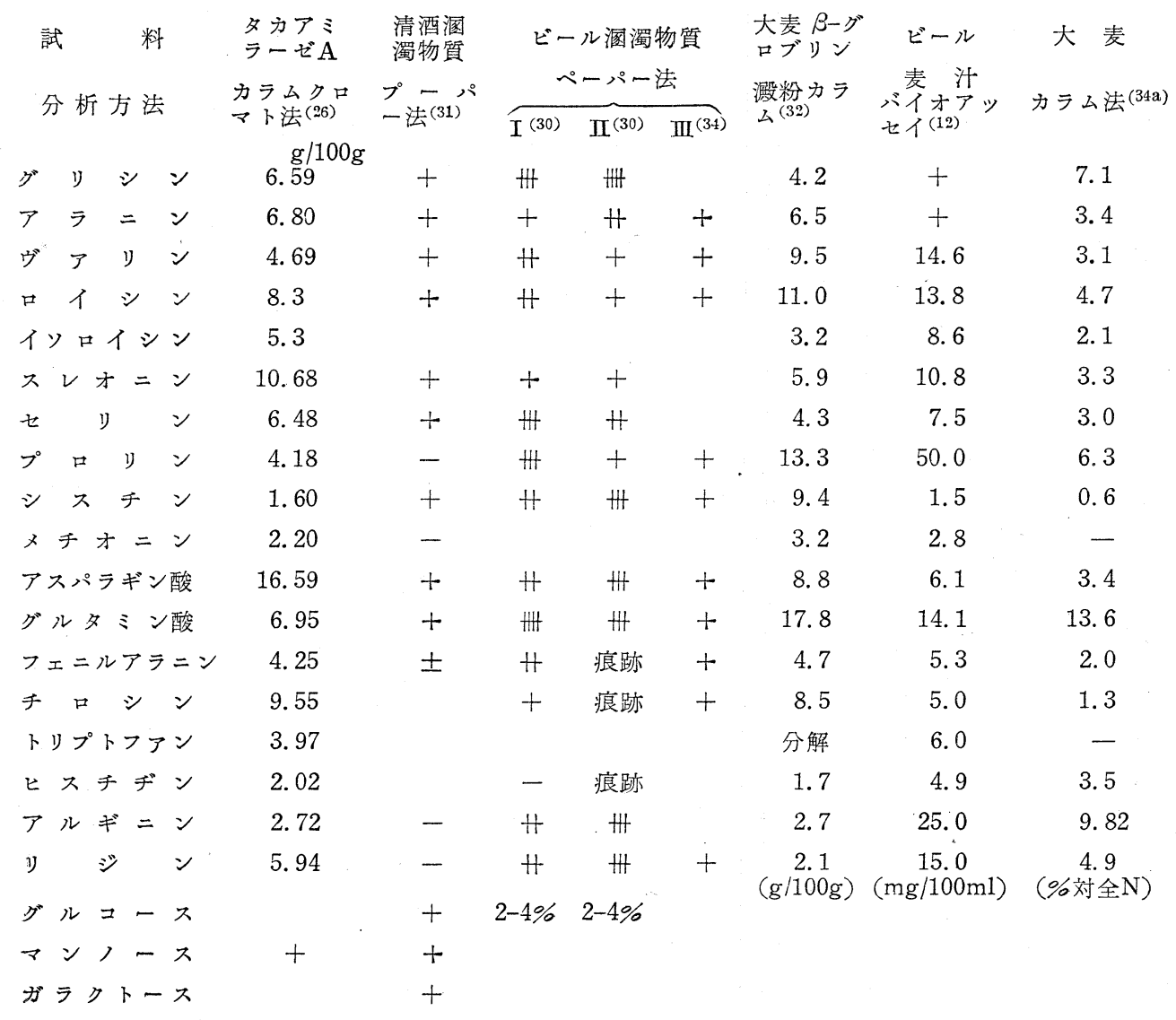




$$
\begin{aligned}
& \text { キシロ }
\end{aligned}
$$

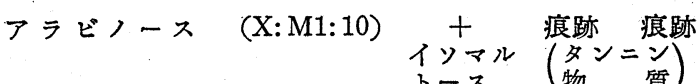

$\left(\mathrm{NH}_{2}\right)$ Ala-Gly-Asp-Ser- $\begin{array}{r}-\mathrm{Ser}(\mathrm{COOH}) \\ \mathrm{Gly}(\mathrm{COOH}) \\ \mathrm{Ala}(\mathrm{COOH})\end{array}$

第 6 図 タカアミラーゼ $\mathrm{A}$ の構造(赤堀)
る。今後清酒のペプチドの研究が行われよう。

ビールのアミノ酸組成及び溷濁物質の成分についても 各種クロマト法により結果が発表されている(第 6 表)。 定量的な問題として再び清酒中のアミノ酸について云え ば明治 41 年高橋先生は清酒 $10 l$ より結晶として 6 種,

3 種を痕跡認めたに過ぎなかつたし, 多田, 塚原氏（昭 16 年）も第 1 表 (10l に換算) の如くであるが, 此れ等は比較的溶解度の低いるのである。チロシンが最も大量分離されている。大高氏によるとチロシンが 多いと酒の「ガラ」が悪くなり，優良酒には一般に少いと云う。アルギニンは大高・田村両氏とも $4 \mathrm{~g}$ 前後 であるものが，山田氏はフラビアネートとして分離し $1.3 \mathrm{~g}$ ，多田氏は 1.8 ，高橋先生は発見し得なかつた。

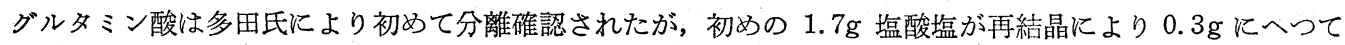
いる。この様に結晶として取る為には溶解度が問題となつているわけである。ここにイオン交換樹脂の役割 が大きくクローズアップされて来る。従来最も鋭敏のアミノ酸の反応はパウリ氏ヂアゾ反応によるヒスチデ ンが $1 / 100,000$ 迄と, 坂口反応でアルギニンが $0.4 \gamma$ 迄検出し得る二方法であつたが, 現在はどのアミノ酸 に対しても濾紙上にニンヒドリン反応でこの程度検出出来る。しかもイオン交換樹脂は数 $\mathrm{mg}$ のアノ酸混 液からも全アミノ酸が定量的に分別出来るから樹脂による分離法とを組合せ, 更に樹脂からの溶出液にアン モニア醋酸等揮発性溶剤を用いると直接結晶を取る事が出来るすぐれた方法と考える。

無機塩も定量的にイオン交換樹脂で分析出来る。東大理学部南英一教授, 本田雅健助教授等(28) は本法によ つて温泉の分析を行つた。独逸のビール醸造用水の分析法 ${ }^{(29)}$ にも酸イオンと金属イオンとの分離にこれを 用い, 酸根の定量を簡便にしている。醸造用水については未だ樹脂応用の報告は見ていないが, 東大農芸化 学嘉納成三氏 ${ }^{(33)}$ は宮水には粼酸成分が多いと云5。宮水は粼酸が $2.5 \mathrm{mg} 1 l$ でこれ程多い水は全国に未だ 見出されず, 普通多くて $1 \mathrm{mg}$ で大体 $0.2 \mathrm{mg}$ 程度である。これが宮水の良いいわれであるかどうかは一概 そは云えないが興味ある問題である。樹脂によれば金属イオンの分別は容易で，2価イオンは EDTA によ るシュバルッェンバッハ法で定量し得るから，水中の Ca 及び $\mathrm{Mg}$ (硬度の問題) の定量にすぐ応用し得る。 又水の蒐集についてる例光ば Amberlite IR-120 と Amberlite IRA-400 (100 メッシュ位) 夫々 20cc 入 りビューレット 1 本宛あれば $500 \mathrm{cc}$ 位の水の全成分は吸着し得るから償につめて各地から運ぶよりも簡易 である。

現今醇造用葡萄糖には殆んどイオン交換樹脂処理と銘打つてあるが，樹脂は脱塩のみではなく，上記の如 く分析にも非常に有用な方法と信ずる。筆者もこのイオン交換樹脂による分析を二, 三行つているが未だ発 表すべき結果を得ていない。

(1) 大高：農化，367 昭 25

\section{文献}

(1a) 田村学造, 角田俊直, 桐村二郎, 宮沢滋：農化, 26, 480(昭 27)

（1b）守随, 坂本, 田島：合技報 6 号 (昭 30), 醱工, 33, 3, 4, 6 号 (昭 30)

（2）大高，合技報，10号 20 (昭 26)

(2a) 猿野: 醱工, 32, 253(1954), 33, 74, 153(1955)

（3）国中：農化，28,282(1954) 農化大会昭 30 年 4 月

(4) W.E. Cohn et al : J.Am. Chem. Soc. 72,147 (1950) 等 令

(5) R.Parsons : J. Inst. Brew. 61, 29(1955)

（6）富金原, 松村：農化, 26,583 , 昭 $27,28,529$, 昭 29 合技報 6 号, 昭 30 , 䁔造論文 10 巻, 昭 29

(7) 津山, 高橋: 醇工, 33,87 (昭 30)

（8）蔹山，杉田：醱工, 31,189 (昭 28)

(9) 岡崎浩：第 8 回酵素化学シンポジウム講演大阪, 農化 29605 (昭 30)

（9a）富金原及び田辺：醱酵協，13，2号，2-14（昭 30)

（10）麻生，柴崎等: 醗工，31 巻より 14 報に亘る。

（11）仙台鑑定官室：醸協，49，1号 31 (昭 29)

(12) E. C. Barton-Wright : Proc. Europ. Brew. Conv. (1953). 98, (1949) 16.

(13) W.D. Mc Farlane \& H. R. Held : Proc. Europ. Brew. Conv. (1953), 110

（14）大高: 合技報, 10 号 24 昭 26 , 昭 29,3 号 24 頁

(15) 川野, 川端: 醱工, $31,184,434$ 昭 $28,32,411,413$ 昭 29, 合技報, 2, 37 昭 28

（16）猿野, 阿野：醗工, 32,323（昭 29) 
（17）大高：農化大会, 昭 30,4 月口演

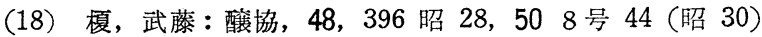

(19) 猿野: 酸工, 32, 370 (昭 29)

(20) 安藤等：醗工, 33,21 (昭 30 )

(21) 山本, 嘉納, 营間: 農化, 27,114 昭 28

(22) 佐藤：醸協，46，3 号 30 昭 26

(23) H. Bush: J. Biol. Chem, 196, 717 (1952), H.S. Owens 等 Anal. Chem. 25, 1507 (1953) 等醸造 分析法 426 頁

(24) Moore 等: J. Biol. Chem. 192,663(1951), 195, 669(1952)

(25) Partridge 等: Biochem. J. 51,628(1952)

（26）赤堀四郎：䣫酵協，13,34（昭 30）醭素化学シンポシウム 9,18(1954)

(27) 赤堀, 迫田等：酵素化学シンポシュム 9,25.(1954)，10,155(1954) 第八回同会口演 ( 7 月大阪)

(28) 南等: 日化, 74,740 (1953)

(29) C. W. Naumann: Das Brauwassr 1954

(30) W. I. Bengough 及び G. Harris: J. Inst. Brew. 61,134(1955)

（31）市川邦介, 井上幸男, 川崎亘: 䁔協, 505 号51（昭 30）

(32) R. Jensen: Acta. Chem. Scand. 6, 771(1952)

(33) 嘉納成三: 農化, 27,881 (1953)

(34) R. Allouf, R. Munier 及び M. Macheboeuf : Proc. Eurp. Brew. Conv. 39(1953)

(34a) L. Ljungdahl 及び E. Sandegren : Proc. Eurp. Brew. Conv., 85(1953)

(35) 山田正一, 石田章, 小林長三郎：䂭試報, 99, 188 (昭 3)

(36) 東恒人: 理研報, 7, 506, 527 (1928)

(37) 守随稀雪, 山本銀三, 杉田修: 䤑協, 45, 12 (昭 25)

(38) 服部行彥: 科研報, 31,2 号 137 (昭 30 )

(39) 山田正一：䂅造分析法, 135 頁

（40）植村定治郎, 中村雄次：醈工，33,203（昭 30)

\section{投、稿 規 約}

1. 原稿は醸造に関する限り次の欄に受汁る。
A. 論 説
B 解 説
C. 随 筆
D. 講演記録
E. 報
文

2. 原稿は他誌に未発表のものに限る。

3. 原稿の取捨は編集部に一任のこと，原稿中の字句については加除修正を行うことがある。

4. 報文は 4000 字 (印刷面約 2 頁) 以内とする。

5. 記述は平がな, 新かなづかいとし，恣語音訳は片かなを用い圥長を避け，簡単明膫なること。

6. 句読点, カッコには一劃間与兄, 別行の篔頭は一字下げること。

7. 図及びグラフは出来るだけ少数に經め, 白紙又は青線方眼に丁寧に墨書すること, 青インキは写し 取りが不可能である。

8. 報文にはなるべく欧文の表題，著者名，結論を添えること。

9. 引用女献㥩著名, 雑誌名, 巻数, 頁数, 年号の順にすること。

10. 報文中の引用交献番号はカッコをつけて肩に小さく書く, 交献は報文の最後に通し番号順に列記する。

11. 校正希望ならば初校を著者校正とするがなるべく編集者に任されたい。

12. 原稿の送付には送状をつけること:

（イ）発送年月日，（口）氏名所属（氏名にはふりがなるりる，（八）連絡先，（二）論文種別，

（ホ）禋題，(へ）原稿枚数，（ト）写真及び図表数，（チ） 備考

13. 投稿及び会誌編集に関する通信並びに原稿用紙（実費申受く）の請求は下記宛に願いすす。

東京都北区滝野川二丁目六 日本䤉造協会編集部＼cjkstart電話王子,局（91）2050 3390 番

\section{研究報交を投稿されるカへ}

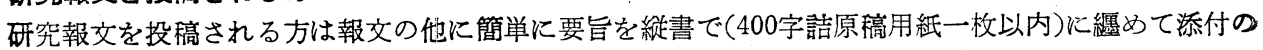
こと,これは報文の末尾につく所謂要約とは別に, 研究内容結果等を簡潔に分り易くまとめたものです。 